\title{
FLOOD OF JULY 1-5, 1978 \\ ON THE KICKAPOO RIVER, SOUTHWESTERN WISCONSIN
}

P.E. HUGHES, J.S. HANNUKSELA, AND W.J. DANCHUK

1981

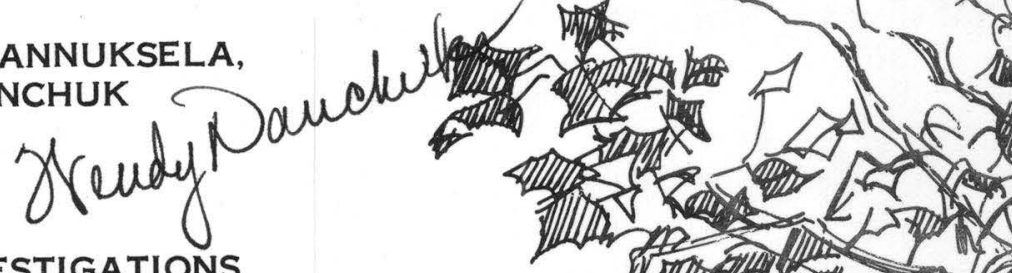

HYDROLOGIC INVESTIGATIONS

ATLAS HA- 653
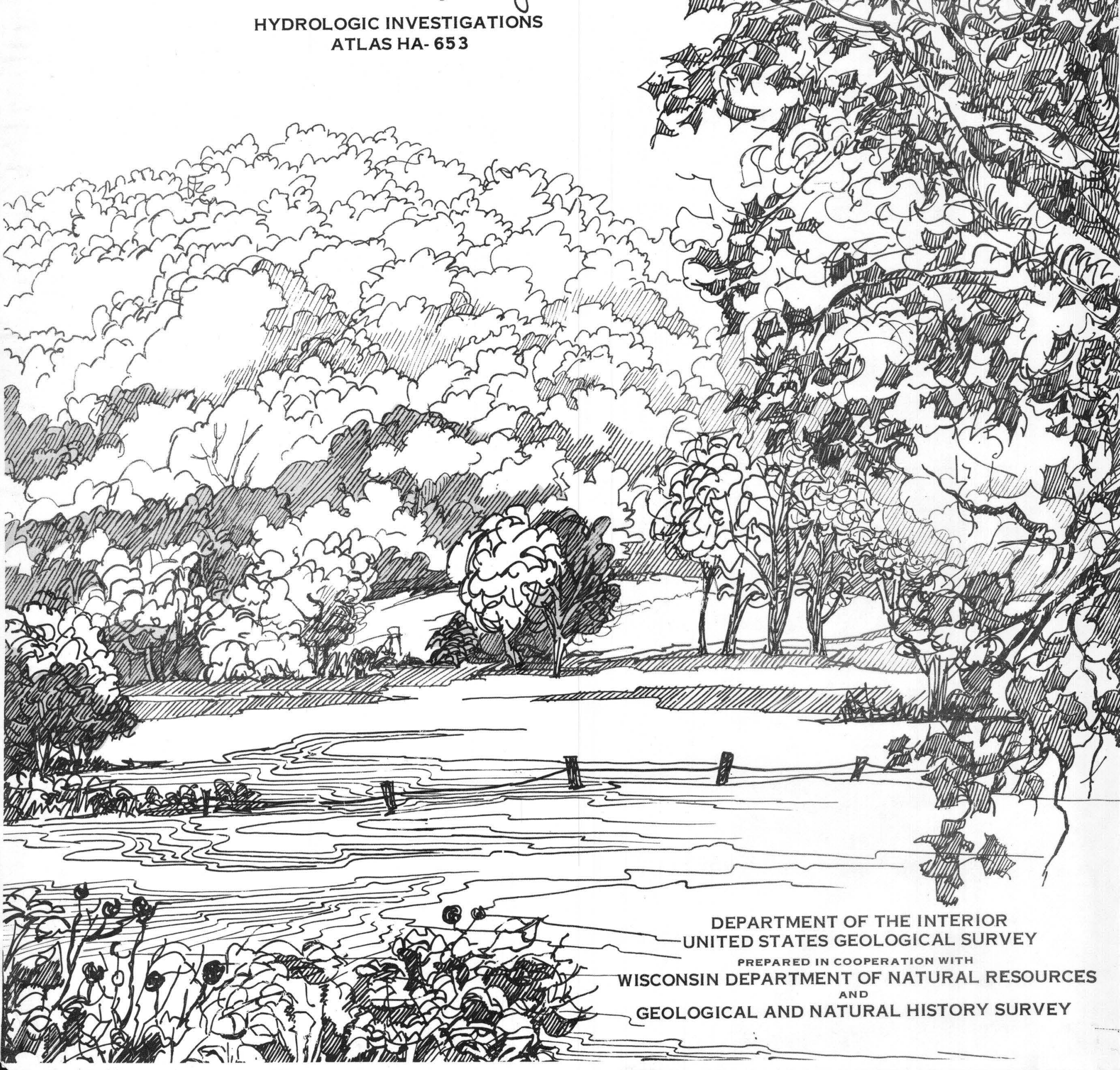